\title{
Efficiency of Urban Development under High-rise Construction of Districts
}

\author{
Irina Ptuhina ${ }^{1}$, Tatiana Spiridonova ${ }^{1}$, Tatiana Musorina ${ }^{1, a}$, Svetlana Kanyukova ${ }^{1}$ and Anna Rezvaia ${ }^{2}$ \\ ${ }^{1}$ Peter the Great St.Petersburg Polytechnic University, Polytechnicheskaya 29, 195251, St.Petersburg, Russia \\ ${ }^{2}$ Magadan Institute of Economics - Branch Office of the Private Educational Establishment of Higher Professional \\ Education Saint-Peterburg, Universi ty of Management and Economics, Magadan, Novaya ul. 27, 685000, Russia
}

\begin{abstract}
In article the problem of irrationally organized massive shabby, including emergency quarters on the example of St. Petersburg reveals. The goal of research: to offer a method of development (renovation) of urban areas by construction of quarters from exclusively high-rise buildings. Because of building of high-rise objects, considered quarters can assume more modern air, increase in the housing areas by 10 times not less in comparison with the previous indicators of this territory, the improved infrastructure of the area, and as a result, emergence of new workplaces. Authors made the analysis of economic indicators of the investment project. The minimum term, for which saved-up income exceeds initial investments (a project payback period) made 2.3 years. The analysis of risks is presented in this article
\end{abstract}

\section{Introduction}

Creation of living conditions, which meeting requirements of Russian society of the XXI century has to be one of the priority directions of social and economic policy of the State. In article the problem of irrationally organized massive shabby, including emergency quarters on the example of St. Petersburg reveals. The main attention in article is focused on a way of renovation of quarters by demolition of outdated buildings and constructions and construction on their place of the high-rise units combining modern requirements to quality of inhabited massifs, infrastructures, production and other capacities. High-rise construction is meant as construction of buildings and structures more than 100 meters. The functional thought-over high-rise buildings concentrate in themselves the high density of infrastructure, or for example, housing stock, releasing a useful area of city lands within the existing megalopolis borders.

There are 18 districts including "painful" quarters at the beginning of 2015 in St. Petersburg, which area makes about 1439 sq.km.

At the first stage of selection of the suitable district for research areas in which according to Highrise regulations it isn't allowed to create high-rise buildings (table 1) were excluded.

Table 1. Characteristic of the districts of St. Petersburg by Russian Regional Information Agency

\begin{tabular}{|c|c|c|c|}
\hline No. & Title of district & Square, $[\mathrm{km} 2]$ & Background height \\
\hline 1 & Admiraltejskiy & 13.82 & --- \\
\hline
\end{tabular}

\footnotetext{
${ }^{a}$ Corresponding author : flamingo-93@mail.ru
} 
MATEC Web of Conferences

\begin{tabular}{|c|c|c|c|}
\hline 2 & Vasileostrovskiy & 14.64 & to $70[\mathrm{~m}]$ \\
\hline 3 & Vyborgskiy & 115.38 & to $100[\mathrm{~m}]$ \\
\hline 4 & Kalninskiy & 40.12 & to $100[\mathrm{~m}]$ \\
\hline 5 & Kirovskiy & 48.00 & to $80[\mathrm{~m}]$ \\
\hline 6 & Kolpinskiy & 105.8 & to $80[\mathrm{~m}]$ \\
\hline 7 & Krasnogvardeyskiy & 56.83 & to $80[\mathrm{~m}]$ \\
\hline 8 & Krasnoselskiy & 115.00 & to $120[\mathrm{~m}]$ \\
\hline 9 & Kronshtadskiy & 19.35 & to $50[\mathrm{~m}]$ \\
\hline 10 & Kurortniy & 267.92 & to $30[\mathrm{~m}]$ \\
\hline 11 & Moscowskiy & 71.07 & to $90[\mathrm{~m}]$ \\
\hline 12 & Nevskiy & 61.79 & to $140[\mathrm{~m}]$ \\
\hline 13 & Petrogradskiy & 24.00 & ---- \\
\hline 14 & Petrodvortcovyj & 109.00 & to $36[\mathrm{~m}]$ \\
\hline 15 & Primorskiy & 109.87 & to $100[\mathrm{~m}]$ \\
\hline 16 & Pushkinskiy & 239.95 & to $50[\mathrm{~m}]$ \\
\hline 17 & Frunzenskiy & 37.47 & to $100[\mathrm{~m}]$ \\
\hline 18 & Thsentralnyj & 17.12 & ---- \\
\hline
\end{tabular}

So, for consideration 6 districts of St. Petersburg in the territory of which construction of high- rise buildings is allocated:

- Vyborgskiy,

- Kalninskiy,

- Krasnoselskiy,

- Nevskiy,

- Primorskiy,

- Frunzenskiy.

On the basis of the analysis of the offered way of renovation of quarters an attempt is made is shown that the method will allow enabling the realization more effectively:

1. Social needs of the population of considered quarters for educational and entertaining resources, sports resources, medical resources, thereby having created the new centers of social and economic development of St. Petersburg.

2. Commercial requirements, by growth of appeal of peripheral territories to placement of industrial and public and business high-rise complexes, and also ensuring high-rise profitability of investments owing to uniqueness of objects.

3. The budgetary requirements - creation of new workplaces and sources of replenishment of the local budget at the expense of taxes [1].

\subsection{Goals and objectives}

Object of research is the extensive method of renovation [2] of the residential quarter by demolition of shabby housing and construction of high-rise buildings in the freed territory.

Subject of research is the assessment of efficiency of carrying out renovation by an extensive method.

The goal of research: to offer a method of development (renovation) of urban areas by construction of quarters from exclusively high-rise buildings.

Objectives: 
- research of problems of reproduction of the dwelling and analysis of a condition of housing stock,

- drawing up an economic assessment before renovation of quarter and after,

- identification and analysis of financial and non-financial forms of the state (municipal) participation in process of renovation of housing stock.

Scientific novelty of work comes to light in use only of high-rise unique buildings and constructions in a method of development (renovation).

\section{Materials and Methods}

\subsection{International experience of urban high-rise construction of districts}

$30 \%$ of a world's population lived in the cities in 1950 . It was $47 \%$ in 2000 . The sum can reach even $60 \%$ by 2030 of also quickly growing urbanization, especially in developing countries, creates a lot of opportunity and problems [23].

Considerable distribution was gained by construction of panel buildings, as well as in Russia, after World war II in Western and Eastern Europe. A lot of buildings considerably became outdated and demanded capital repairs by 1980-2000th years. Panel buildings in Europe, as well as in Russia, were also inefficient, because considerable costs of repair and operation, low popularity among tenants and buyers from a commercial point of view. So, in 2000 renovation of a mass housing estate became one of priority tasks in Europe.

Many realized projects of renovation it is possible to note in such countries as Germany, Poland, Lithuania, the Netherlands, Romania, France and England. Development of projects of renovation of a housing estate happens due to reconstruction of houses or due to partial or full demolition of buildings and construction new. The significant role at their realization is played by public opinion of researches, public hearings, presentations of projects are conducted. Also through mass media it is told residents about the course of works.

Building of quarters can be both multifunctional, and single-function.

The only example of single-function high-rise office building in the city Frankfurt am Main onefunctionality is determined by historically developed city role as all-European financial center. Today in the city offices of 400 largest banks are concentrated. According to the general function their compact placement in the uniform business high-rise downtown could be represented expedient.

Successfully projects in Paris are "The Front of Seine", and then a multipurpose complex La Défense on the western suburb of the city which replaced invaluable chaotic suburban building (Nanterre, Pyuto, Kurbevua). Building of the area La Défense became the largest and effective example of realization of the European principles of the integrated urbanism. Multifunctional building provided the round-the-clock bright rich life of the area. Concentration of high-rise office building on the suburb of the city relieved historical central building of Paris of inevitable reconstruction at placement in it new office objects and brought economic revival: in offices of La Défense about $80 \%$ of agreements and transactions in economy of France are annually concluded.

Large-scale town-planning reconstruction of an outdated industrial zone of the city was in London. There are an area of docks (Doklend) stretched on both coast of the Thames on more than $10 \mathrm{~km}$ to the east from the Tower was made. The State investments were pulled for this project and then investments of private investors for which the government planned essential tax privileges and big state subsidies for 10-year term went. The concept of reconstruction provided creation of a multipurpose urban environment with office center, various cultural and manufacturing enterprises, housing estate for people with various income, schools, medical and other institutions of infrastructure, parks which are arranged well by foot embankments, reservoirs and their coast. The first built in 1991 at that time the highest in Europe tower office Kanari-Verf (height of $245 \mathrm{~m}$ ). Here it is supposed to build not less than 104 thousand new dwellings and to provide to 249 thousand new workplaces till 2016. 
Russian builders can adopt practical experience of consecutive concentration of forces on the extremely limited number of sites from the European builders, as, for example, La Défense in Paris or Doklend in London, and also ensuring complexity of building at the expense of a combination of objects of a different functional purpose in buildings which space-planning decision most harmoniously answers its function that means creation of multifunctional skyscrapers, and also combination in construction of different buildings of different function [24].

\subsection{Concept of renovation of housing stock, justification of a choice of renovation method}

Renovation of housing stock - is a process of replacement and restoration of the elements of housing stock (residential buildings and their parts) which left as a result of functional and physical wear with new elements or objects [2].

Renovation of housing stock is a cyclic process including generally sequence of transformations of housing renovation methods, which are a new construction, overhaul, modernization, restoration and reconstruction, demolition of residential buildings and construction of new objects [2]. The last way is considered in this article, and it is carried out by means of wrecking of the existing building and repeated construction of buildings on the released land plots.

The author of the thesis Khokhlov, O.B [2] specified in the research that among different ways of renovation demolition and new construction is the most perspective method (table 2).

Table 2. Main economic results of realization of methods of renovation of housing stock

\begin{tabular}{|c|c|c|c|}
\hline \multirow{2}{*}{ Renovation methods } & \multicolumn{2}{|c|}{ Results of renovation process } \\
\cline { 2 - 4 } & $\begin{array}{c}\text { Growth of the } \\
\text { income from } \\
\text { operation of } \\
\text { object }\end{array}$ & $\begin{array}{c}\text { Decrease in } \\
\text { costs of } \\
\text { operation } \\
\text { of object }\end{array}$ & $\begin{array}{c}\text { Increase in } \\
\text { service life of } \\
\text { structures and } \\
\text { object in } \\
\text { general }\end{array}$ \\
\hline Demolition and new construction & + & + & + \\
\hline Strengthening of bearing structures & & + & + \\
\hline Modernization of engineering communications & & + & + \\
\hline $\begin{array}{c}\text { Installation of systems of the account and } \\
\text { regulation of a water consumption and energy } \\
\text { resources }\end{array}$ & & + & + \\
\hline Re-planning and reshaping of rooms & + & + & + \\
\hline Strengthening of thermal insulation & & & + \\
\hline Extension, superstructure of rooms & + & & + \\
\hline
\end{tabular}

Secondary building of the territory by high-rise buildings is a convenient way of renovation of quarter by means of which conditions of accommodation of the population improve, the quantity of shabby housing in the area decreases, there are large volumes of new inhabited space, and, therefore, and security of the population with housing increases, the infrastructure and improvement of the territory improves. Thus it isn't required development of new territories, because the site of building remains within the available borders [3].

\subsection{The characteristic of the considered quarter and the description of a condition of housing stock}


Authors of this article made an attempt to consider a possibility of renovation of the quarter which is situated in Nevskiy district in the territory limited to streets Karavayevsky and Teplovoznoy, Slepushkin and Skachkov's lanes and makes 141129.6 sq.m (see fig. 1). The distance to historic center is $18.7 \mathrm{~m}$.

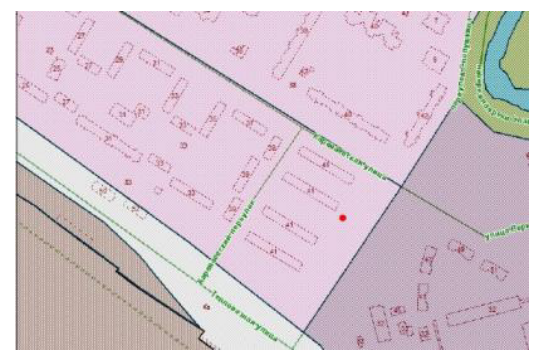

Figure 1. Fragment of quarter

The maximum background height is $110 \mathrm{~m}$ on the considered territory. There are 25 houses are situated now in the territory of the quarter.

Zone is inhabited for middle- and multi-storey multi-flats houses located out of the territory of historically developed districts of St. Petersburg's center with inclusion of objects of welfare and household appointment. Quarter borders from Karavayevskaya st. on a fire brigade.
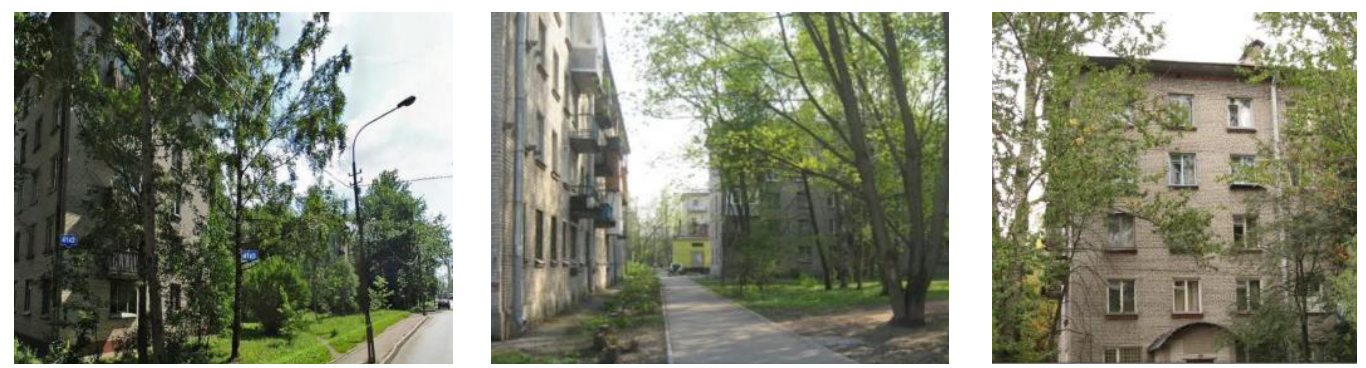

Figure 2. Karavayevskaya st. - a) panorama of the street. b) and c) courtyard

All houses, which are situated in the territory of this quarter (see fig. 2, table 3), were made in accordance with project of Series 1-528KP. Usually, people calls such houses "Brezhnevky". A brick series $1-528 \mathrm{KP}$, actively was under construction in suburbs in Leningrad. There are exist more than two tens modifications of different number of storey from two to five, and also quantity of front doors from two to eight in the nomenclature. Features of these houses are qualitative parquet, panel framed doors and well-adjusted window frames. There are enough high ceilings $(2.5 \mathrm{~m})$, small kitchens and halls, existence of several adjacent rooms [4-5].

General characteristics of a Series 1-528KP are:

- houses are made from bricks,

- there are about 2-5 storeys,

- height of premises is $250 \mathrm{~cm}$

- the number of rooms are 1.2 , and 3 room in a one flat,

- it usually makes with local building materials,

- years of construction are 1959-1975.

- cities of distribution are St. Petersburg and Nizhny Novgorod Novgorod [22]. Table 3. General analysis of infrastructure of the district 
Table 3. The situation in the quarter

\begin{tabular}{|c|c|c|}
\hline Type & Number and distance & Additional \\
\hline Restaurants and cafe & $8(1-1.5[\mathrm{~km}])$ & "McDonald's", "KFC" ets. \\
\hline shopping mall & $2(1[\mathrm{~km}])$ & "Parade" mall, "Port Nakhodka" mall \\
\hline Hotels & $2(5[\mathrm{~km}])$ & Hotel in Metallostroy \\
\hline Leasure & many in historical center, a lot of in \\
district & \\
\hline Main sightseeings & 2 fitness clubs & \\
\hline Health-improving zone & 7 & \\
\hline Educational centres & Rybatskoye 1 & \\
\hline Medicine & $\begin{array}{c}\text { Government's Clinique for children, } \\
\text { more than 5 private clinics for adults }\end{array}$ & \\
\hline Suway (underground) & nearby subway, more than 10 routes & \\
\hline Buses & nearby subway, more than 10 routes & \\
\hline Fixed-run taxis & Rybatskoye & \\
\hline Railway station & & \\
\hline & & \\
\hline
\end{tabular}

\subsection{Sequence of implementation of renovation}

Participation of the State in renovation, research of the processes, which are connected with resettlement of residents.

It is supposed that responsibility for demolition of available buildings, cleaning of the territory of construction garbage and sale of a site are assumed by the state. Therefore, the municipality of the area "prepares" a site for sale and enables its realization at auction specifically for construction of a new residential building.

Possible ways of resettlement of residents at demolition of a residential building are shown in table 4.

Table 4. Ways of resettlement of residents at demolition of a residential building is possible in...

1.... in the new housing acquired in primary market, also in the territory of Nevskiy district 2....in the housing acquired in the secondary market, also in the territory of Nevsky district
3. ....in the new housing constructed on a place of demolished objects

Authors choose the third way in this article, because it allows to make:

1. often renovation for many inhabitants is a social stress, citizens could get used to a residence and have difficulties with process of resettlement on a constant basis,

2. use the aspect of quality improvement of inhabited environment for residents, who live in 
"Brezhnevka" for confirmation of effectiveness of considered method of renovation allocating.

This way has additional difficulty, which is the need of providing residents with the lodging.

Authors of the thesis [2] claim that nevertheless "even with a growth of average security with housing, the share of the people having housing of "low" quality doesn't decrease". Really, such problem has a wide circulation in the territory of St. Petersburg, but by sight authors of this article can be found the ways allowing "to go to a meeting" to the population, having reduced housing cost, for example, by means of cooperation of government bodies and commercial banks to present the most favorable conditions for receiving a mortgage in the new building, for example, to young families [69].

Thus, it is necessary to move temporarily previously before dismantle of buildings for the residents living in the territory of the quarter captured by renovation processes.

Let renovation of the I-IV buildings 41 on Karavayevskaya st. will become the first step. Therefore, it will be required to settle in removable housing of 400 families (100 families live in each house). And here, the first difficulties connected with requirement of receiving at the initial stage of rather large volume of investments are possible. By authors of article it was calculated that as of January, 2015 the total amount allocated for temporary resettlement of residents for 3 years (for estimated time of duration of construction of the new high-rise building), has to make about 3,5 billion rubles in case of moving on leased squares. It is important to note that in case of moving on the squares relating to the state funds of reserve housing, the sum considerably will decrease depending on reduction of a rent [10-12].

According to Russian Housing Codes the maintenance responsibility and repair of residential buildings of the privatized areas lies on owners of housing. But it is impossible to carry out renovation, because in a year on routine maintenance and overhaul repairs residents of four cases of the forty first house pay in the sum about 50000 rubles. These means will be enough only for payment of cargo transport for implementation of transportation of personal belongings of residents of three of four houses on a temporary residence for comparison [13-15].

\subsection{Participation of commercial subjects of renovation}

The project of renovation of quarter, first of all, is the investment project, where can be used by investors not only the State sources of financing, but also sources from other subjects of the market relations, in other words, non-budgetary sources.

Thus, who can invest in renovation of the considered quarter?

- the population, due to accumulative effect from monthly payment under the article "capital repairs",

- commercial subjects, at the expense of an investment of own and borrowed funds, for example, the bank credits.

- public funds, for example, budgetary funds and means of trust off-budget funds [16].

\section{Results and Discussion}

\subsection{Efficiency of the project of renovation by construction on a place of demolished buildings of high-rise buildings}

Economic effect demonstrates the difference between results of economic activity (for example, a product in value terms) and the expenses made for their receiving and use.

The project of renovation of quarter, as it has already written in paragraph 3 , is investment project and consequently it is necessary to prove to investors that the project investment and attractive therefore it is necessary to calculate efficiency of implementation of the project [19-21].

Let from 25 available in the territory of the considered quarter of 4 buildings (41, I-IV parts) will be accepted as the first step (table 5). Construction of one high-rise building is planned in the territory 


\section{MATEC Web of Conferences}

of these buildings. It is possible to consider social and economic efficiency of such project on this example [17-18].

Table 5. Characteristic of objects of renovation (1st step)

\begin{tabular}{|c|c|c|}
\hline Indicators & Values for one house & Values for four houses \\
\hline $\begin{array}{c}1 . \text { Number of flats } \\
\text { Including in private property, in government } \\
\text { property }\end{array}$ & $\begin{array}{l}100 \\
60 \% \\
40 \%\end{array}$ & $\begin{array}{l}400 \\
60 \% \\
40 \%\end{array}$ \\
\hline 2. General square of flaats, $\mathrm{m} 2$ & 4000 & 16000 \\
\hline 3. Number of families & 100 & 400 \\
\hline 4. Number of floors & \multicolumn{2}{|c|}{5} \\
\hline 5. Number of entrances & 5 & 25 \\
\hline 6. Management company & \multicolumn{2}{|c|}{ „Ryb.-Stroyservice“ } \\
\hline 7. District & \multicolumn{2}{|c|}{ Nevskiy } \\
\hline 8. Year of construction & \multicolumn{2}{|c|}{1975} \\
\hline 9. Physical deterioration & \multicolumn{2}{|c|}{$60 \% *$} \\
\hline 10. Volume of building, $\mathrm{m} 3$ & 58600 & 234400 \\
\hline $\begin{array}{l}\text { 11. Market cost of } 1 \mathrm{~m} 2 \text { of } \\
\text { general square, rub. }\end{array}$ & \multicolumn{2}{|c|}{83,000} \\
\hline 12. Market cost of all general square, rub. & 334500000 & 1338000000 \\
\hline Contributions to capital repairs, rub per year & 11364 - per month & 45456 \\
\hline $\begin{array}{l}\text { 13. The average cost of rent is } 1 \text { sq.m of housing, } \\
\qquad \begin{array}{c}\mathrm{rub} / \text { month } \\
* *\end{array}\end{array}$ & \multicolumn{2}{|c|}{496 (without utilities) } \\
\hline
\end{tabular}

Note: * Physical deterioration is accepted conditionally for calculation, isn't the valid wear of the considered building

** The average cost of rent of cubic meter of housing without utilities is accepted.

Before an assessment of efficiency it is necessary to define what finantial streams will be considered in calculations [2]. The interval of time of investment into the project is $\mathrm{T}=3$ years, it was accepted as the horizon of an assessment of financial streams (table 6, table 7, table 8).

Table 6. Project of renovation of the residential building 41, building of I.

\begin{tabular}{|c|c|}
\hline \multicolumn{2}{|c|}{ Calculation horizon period } \\
\hline $\mathrm{t}=0-1$ st year & $\mathrm{t}=1-3$ years \\
\hline $\begin{array}{c}\text { Demolition, resettlement of residents and building of new } \\
\text { object }\end{array}$ & End of investment, settling of residents \\
\hline
\end{tabular}


Table 7. Basic data on the project of new construction

\begin{tabular}{|c|c|c|c|}
\hline Calculation of outcoming money & Square, $[\mathrm{m} 2]$ & $\begin{array}{l}\text { Cost of } 1 \\
{[\mathrm{~m} 2]}\end{array}$ & The total cost \\
\hline Construction cost of $1 \mathrm{~m} 2$ of the city & & 80000.00 & \\
\hline building area & 196000 & & \\
\hline The cost of construction & & & 15680000000.00 \\
\hline built-up area & 16000 & & \\
\hline The cost of land $1 \mathrm{~m} 2$ & & 15000.00 & \\
\hline Value of the land & & & 240000000.00 \\
\hline $\begin{array}{l}\text { Design and operation izyskat } 3 \% \text { of the cost of } \\
\text { building. }\end{array}$ & 0.03 & & 470400000.00 \\
\hline Field supervision of $0.2 \%$ & 0.002 & & 31360000.00 \\
\hline Technical supervision $0.1 \%$ & 0.001 & & 15680000.00 \\
\hline Non-investment costs costs $2 \%$ of the value & 0.02 & & 313600000.00 \\
\hline The total cost total & & & 16751040000.00 \\
\hline The cost of construction of $1 \mathrm{~m} 2$ & & & 85464.49 \\
\hline Calculation of incoming money & & & \\
\hline $\begin{array}{l}\text { selling price of } 1 \mathrm{~m} 2 \text { to } 25 \text { thousand more than } \\
\text { the actual }\end{array}$ & & 110464.49 & \\
\hline Estimated inflow from sales & & & 21651040000.00 \\
\hline The distribution of data of outcoming money & & & \\
\hline $\begin{array}{c}0 \text { year (cost of land, design and izyskatelkie } \\
\text { work) }\end{array}$ & & & 710400000.00 \\
\hline $\begin{array}{c}\text { Costs in future years with } 1 \text { to } 3 \text { (total price } \\
\text { minus costs year } 0 \text { ) are }\end{array}$ & & & 16040640000.00 \\
\hline 1 year $35 \%$ & 0.35 & & 5614224000.00 \\
\hline 2 year $40 \%$ & 0.4 & & 6416256000.00 \\
\hline 3 year $25 \%$ & 0.25 & & 4010160000.00 \\
\hline Total otok the period from 0 to 3 years & & & 16751040000.00 \\
\hline Money distribution by years ( $10 \%$ risk $)$ & & & \\
\hline 0 year $0 \%$ & 0 & & 0.00 \\
\hline 1 year $10 \%$ & 0.1 & & 2165104000.00 \\
\hline 2 year $50 \%$ & 0.5 & & 10825520000.00 \\
\hline \multirow[t]{2}{*}{3 year $30 \%$} & 0.3 & & 6495312000.00 \\
\hline & & & 19485936000.00 \\
\hline
\end{tabular}


MATEC Web of Conferences

Table 8. Calculation of NPV

\begin{tabular}{|c|c|c|c|c|c|c|c|c|c|c|c|}
\hline \multirow[b]{2}{*}{ 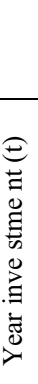 } & \multirow[b]{2}{*}{ 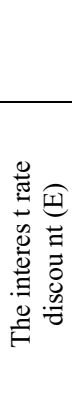 } & \multirow[b]{2}{*}{ 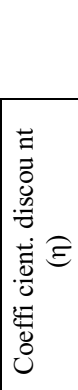 } & \multicolumn{3}{|c|}{$\begin{array}{l}\text { Characteristics of capital } \\
\text { investments (outflow) }\end{array}$} & \multicolumn{3}{|c|}{ Features inflow } & \multicolumn{3}{|c|}{ Features income } \\
\hline & & & 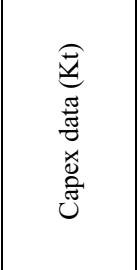 & 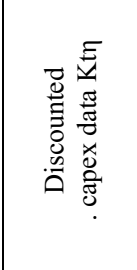 & 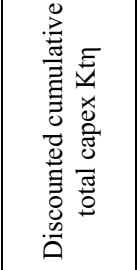 & 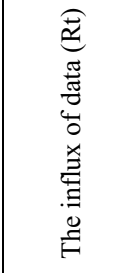 & 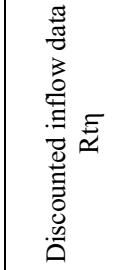 & 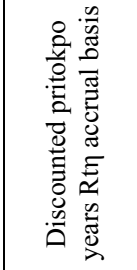 & 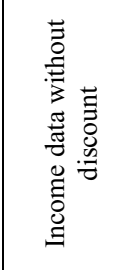 & 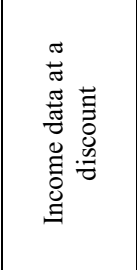 & 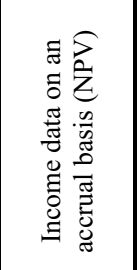 \\
\hline 0 & 0.2 & 1.000 & 578400.00 & 578400,00 & 578400.00 & 0.00 & 0.00 & 0.00 & 578400.00 & $\begin{array}{c}- \\
578400.00\end{array}$ & $\begin{array}{c}- \\
578400.00\end{array}$ \\
\hline 1 & 0.2 & 0.833 & $\left|\begin{array}{c}5 \\
614224.00\end{array}\right|$ & $\begin{array}{c}4 \\
678520.00\end{array}$ & $\begin{array}{c}5 \\
256920.00\end{array}$ & $\begin{array}{c}2 \\
151904.00\end{array}$ & $\begin{array}{c}1 \\
793253.33\end{array}$ & $\begin{array}{c}1 \\
793253.33\end{array}$ & $\begin{array}{l}-3462 \\
320,00\end{array}$ & $\begin{array}{c}-2 \\
885 \\
266.67\end{array}$ & $\begin{array}{c}-3 \\
463666.67\end{array}$ \\
\hline 2 & 0.2 & 0.694 & $\mid \begin{array}{c}6 \\
416256.00\end{array}$ & $\begin{array}{c}4 \\
455733.33\end{array}$ & $\mid \begin{array}{c}9 \\
712653.33\end{array}$ & $\begin{array}{c}10 \\
759620.00\end{array}$ & $\begin{array}{c}7 \\
471958.33\end{array}$ & $\begin{array}{c}9 \\
265 \\
211.67\end{array}$ & $\begin{array}{c}4 \\
343364.00\end{array}$ & $\left|\begin{array}{c}3 \\
016225.00\end{array}\right|$ & 447441.67 \\
\hline 3 & 0.2 & 0.579 & $\begin{array}{c}4 \\
010160.00\end{array}$ & $\begin{array}{c}2 \\
320694.44\end{array}$ & $\begin{array}{c}12 \\
033347.78\end{array}$ & $\begin{array}{c}6 \\
455712.00\end{array}$ & $\begin{array}{c}3 \\
735944.44\end{array}$ & $\begin{array}{c}13 \\
001156.11\end{array}$ & $\begin{array}{c}2 \\
445552.00\end{array}$ & $\mid \begin{array}{c}1 \\
415 \\
250.00\end{array}$ & 967808.33 \\
\hline & & & $\mid \begin{array}{c}16 \\
619040.00\end{array}$ & $\begin{array}{c}12 \\
033347.78\end{array}$ & & $\begin{array}{c}19 \\
367236.00\end{array}$ & $\begin{array}{c}13 \\
001156.11\end{array}$ & & $\begin{array}{c}2 \\
748196.00\end{array}$ & 967808.33 & \\
\hline
\end{tabular}

Result:

NPV - 967808.33 rub, Index of profitability - 1.08, Payback period -2.3 years. Calculation results are presented in Figure 3 and 4.

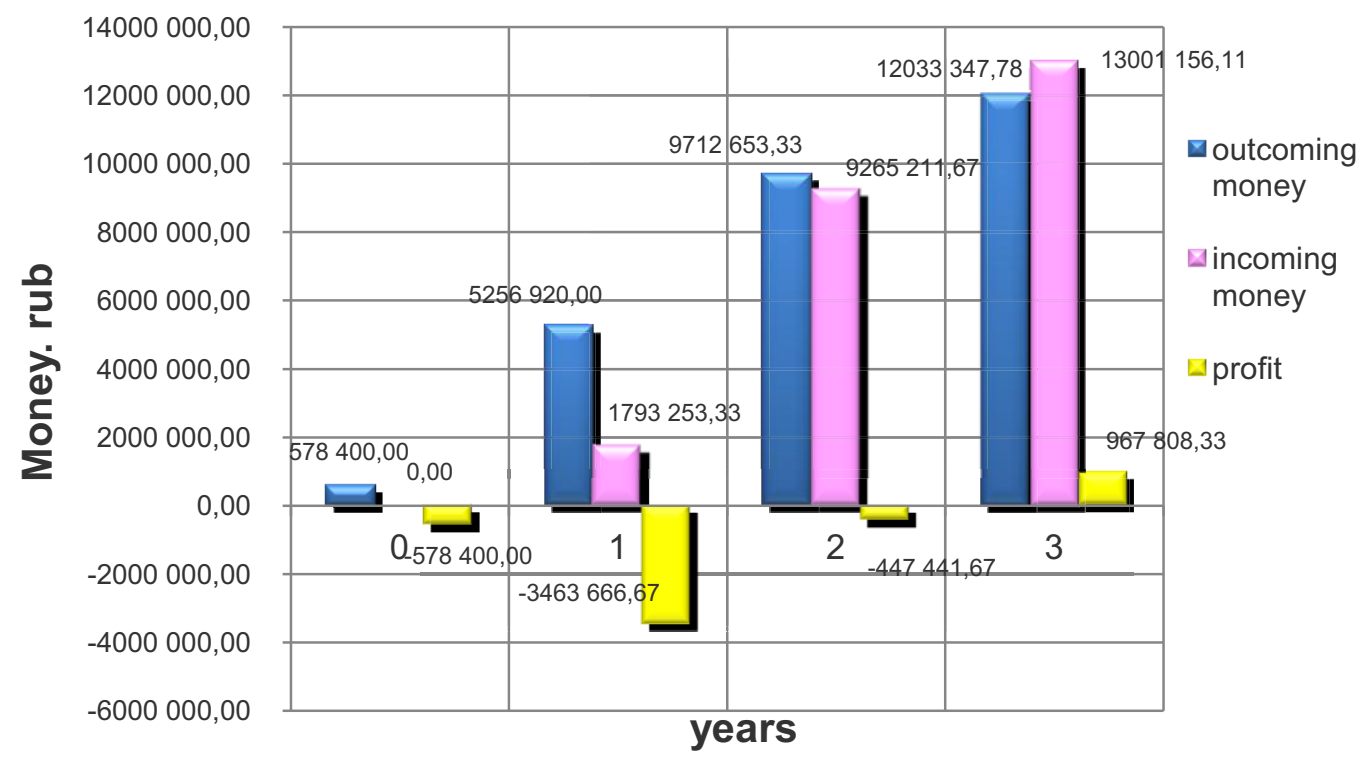

Figure 3. Characteristics of payback period 


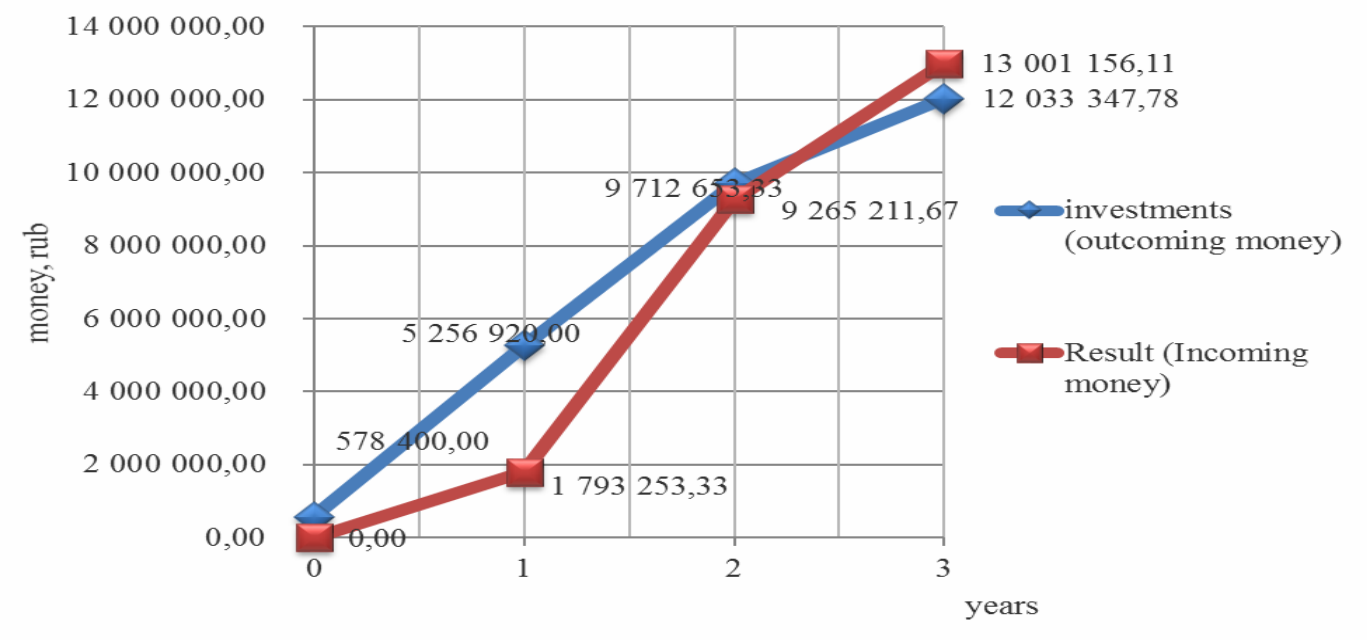

Figure 4. Characteristics of incoming, out coming money and profit

Let us assume that renovation would be carried out construction of a new building, but not the high-rise and ldf 15-17 storey. Then, on the basis of a similar calculation we take the values of NPV

$-300716.38 \mathrm{rub}$, Index of profitability -1.18 and payback period -1.875 years. Thus, there is an opportunity approximately to estimate and compare possible technical and economic risks.

Factors of economic risk are change in discount rate $\mathrm{E}=18 \%$, change in discount rate $\mathrm{E}=20 \%$, errors in budgeting and appreciation of resources.

Factors of technological risk are errors in project documentation, violation of technology of performance construction installation works, low professional level and violation of the schedule diagram of performance of installation and construction works.( Results are seen in Table 8.1, 9, 10)

Table 8.1. Supposed characteristics of projects

\begin{tabular}{|c|c|c|c|c|}
\hline \multirow{2}{*}{ (i) } & \multicolumn{2}{|c|}{ Project of high-rise construction (1) } & \multicolumn{2}{c|}{ Project of building with 15-17 floors (2) } \\
\cline { 2 - 5 } & $\begin{array}{c}\text { The probability of } \\
\text { getting result (pi) }\end{array}$ & $\begin{array}{c}\text { Value of of the } \\
\text { result (ci) }\end{array}$ & $\begin{array}{c}\text { The probability of } \\
\text { getting result (pi) }\end{array}$ & $\begin{array}{c}\text { Value of of the } \\
\text { result (ci) }\end{array}$ \\
\hline 1 & 0.40 & 967.80 & 0.35 & 360.84 \\
\hline 2 & 0.25 & 483.90 & 0.45 & 0.00 \\
\hline 3 & 0.35 & 871.02 & 0.20 & 300.70 \\
\hline
\end{tabular}

Table 9. Risk assessments of investment project

\begin{tabular}{|c|c|c|}
\hline \multirow{2}{*}{ Indicators } & \multicolumn{2}{|c|}{ Number of investment projects } \\
\cline { 2 - 3 } & $\mathrm{P}$ & Projec \\
\hline The mathematical expectation of profit & 812.95 & 186.43 \\
\hline The dispersion of earnings & 37840.13 & 28898.39 \\
\hline The standard deviation of earnings & 194.53 & 170.00 \\
\hline The coefficient of variation & 0.24 & 0.91 \\
\hline
\end{tabular}


Table 10. Assessment of borders of the most possible profit on projects

\begin{tabular}{|c|c|c|}
\hline \multirow{2}{*}{ Indicators } & \multicolumn{2}{|c|}{ Number of investment projects } \\
\cline { 2 - 3 } & $\mathrm{P}$ & Project \\
\hline The upper limit of the possible profit & 1396.5 & 696.4 \\
\hline The lower limit of the possible profit & 229.4 & -323.6 \\
\hline
\end{tabular}

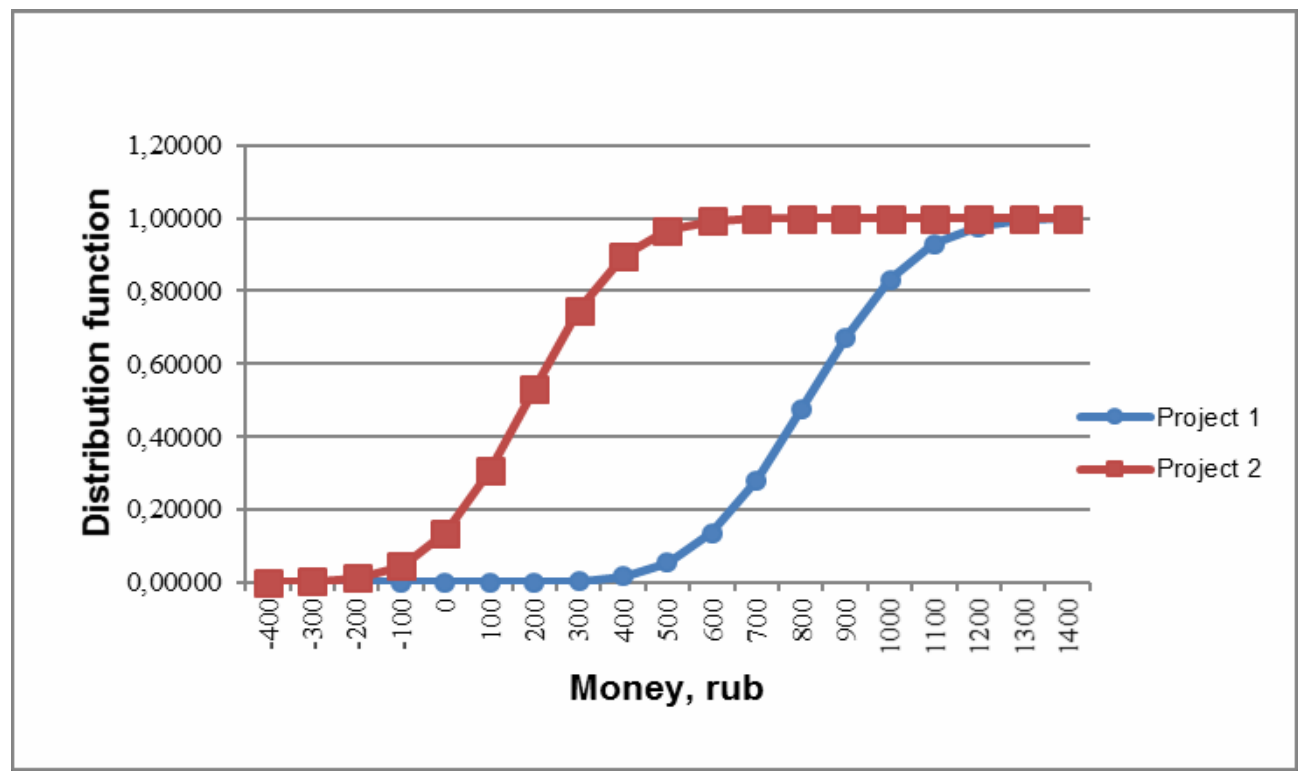

Figure 5. Distribution function of possible profit

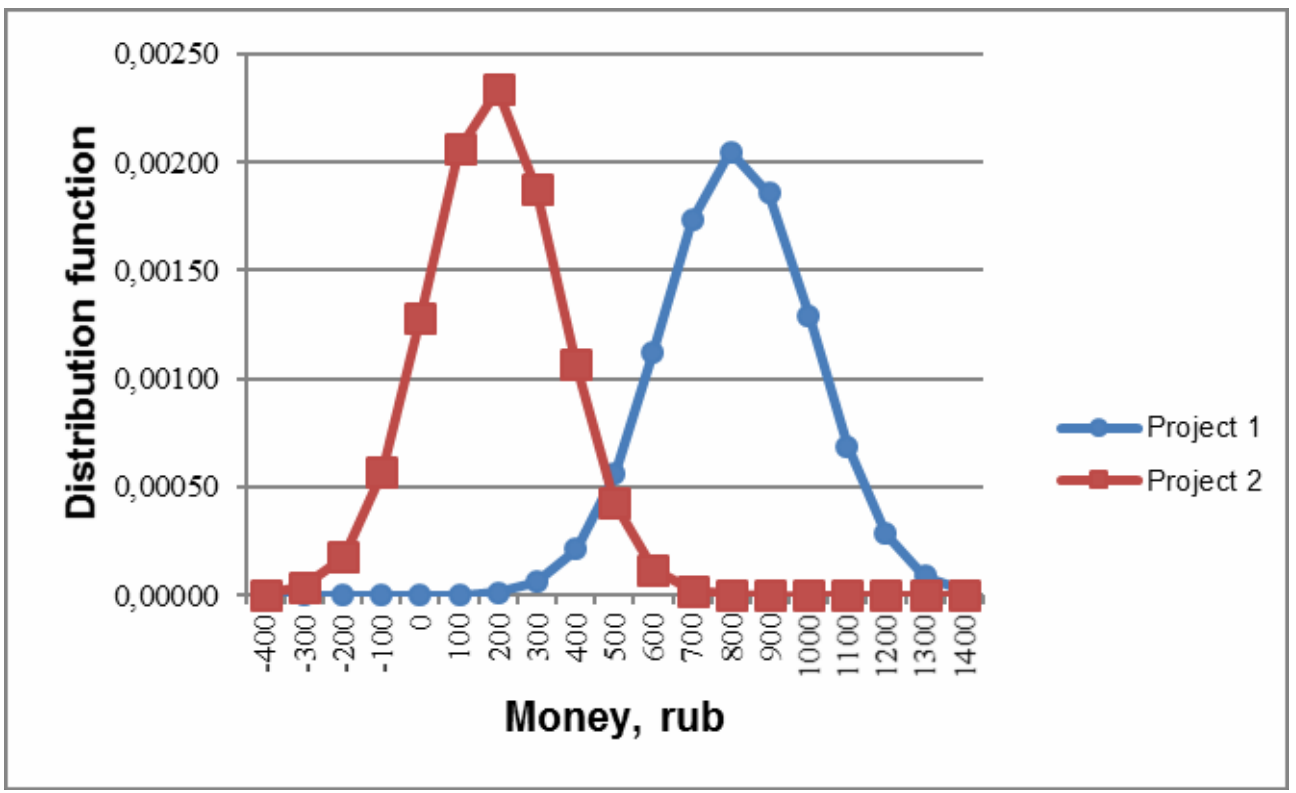

Figure 6. Distribution of density of possible profit 
The possible profit makes: from 229.4 million rubles to 1396.5 million rubles at economic risks and from -323.6 million rubles to 696.4 million rubles at technological hazards by results of calculation of economic and technological risks for the first project (see Figure 5 and 6). Cooperation with insurance companies will allow reducing probability of economic risks [22].

\section{Conclusions}

1. The problem of reconstruction of shabby quarters can be solved with the help of demolition of housing which doesn't meet modern requirements of quality, and construction on a place of the demolished buildings of skyscrapers. Because of building of high-rise objects, considered quarters can assume more modern air, increase in the housing areas by 10 times not less in comparison with the previous indicators of this territory, the improved infrastructure of the area, and as a result, emergence of new workplaces.

2. Authors made the analysis of economic indicators of the investment project. The project 35 of a floor skyscraper is considered economically effective: in three years of investment the house will bring in the income in 967808.33 thousand rubles. Efficiency of investments is more than unit, namely the index of profitability is equal 1.08. The minimum term, for which saved-up income exceeds initial investments (a project payback period) made 2.3 years.

Renovation by demolition of shabby housing and construction of new buildings on a place of the taken down is the most favorable way of renovation owing to which advantages are got by both the state, and commercial investors.

3. The first project of high-rise renovation is more "safety" than the second as even taking into account economic and technological risks as the minimum border of possible profit can be positive.

4. Russian builders can adopt practical experience of consecutive concentration of forces on the extremely limited number of sites from the European builders and ensuring complexity of building at the expense of a combination of objects of a different functional purpose in buildings which spaceplanning decision most harmoniously answers its function that means creation of multifunctional skyscrapers, and also combination in construction of different buildings of different function

\section{References}

1. A.A. Uversky, O.G. Nikonov, Construction of Unique Buildings and Structures, 4 (19), 139-150 (2014).

2. O.B. Khokhlov, Performance evaluation of projects and programs renovation housing (Thesis, Tomsk, 2006)

3. Ptuhina, T. Spiridonova, T. Musorina, Applied Mechanics and Materials, 725- 726, 153-159 (2015).

4. M. Petrichenko, X. Rakova, M. Vyatkin, T. Musorina, D. Kuznetsova, Applied Mechanics and Materials, 725-726, 1101-1106 (2015)

5. N. Lipovac, A.M. Jandriček, Prostor, 19 (2), 443-455 (2011)

6. Z.A. Gaevskaya, X.M. Rakova, Advanced Materials Research, 941-944, 825-830 (2014)

7. N.S. Bolshakov, S.A. Krivoy, X.M. Rakova, Advanced Materials Research, 941- 944, 895-900 (2014)

8. Ptuhina, M. Viatkin, T. Musorina, Construction of Unique Buildings and Structures, 9 (14), 46$56(2013)$

9. O.N. Popova, T.L. Simankina, Magazine of Civil Engineering, 7 (42), 40-50 (2013)

10. I. Čerpes, N. Pandol, A. Fikfak, European Countryside, 6 (3), 225-242 (2014)

11. C. Zappulla, C. Suau, A. Fikfak, Journal of Architecture and Urbanism, 38 (4), 247-264 (2014)

12. A. Fikfak, Journal of Architecture and Urbanism, 37 (4), 257-267 (2013)

13. T. Teslya, T. Spiridonova, Construction of Unique Buildings and Structures, 7 (12), 5-9 (2013)

14. J. Tamošaitienè, J. Šipalis, A. Banaitis, E. Gaudutis, International Journal of Strategic property and Management, 17 (1), 92-108 (2013) 


\section{MATEC Web of Conferences}

15. Ptuhina, M. Viatkin, T. Musorina, Construction of Unique Buildings and Structures, 5 (10), 5867 (2013)

16. J. Tamošaitienèa, E. Gaudutis, M. Kračkaa, Procedia Engineering, 57, 1151-1155 (2013)

17. K. Al-Kodmany, Journal of Urban Technology, 18 (3), 115-140 (2011)

18. http://gov.spb.ru/gov/terr/ (date of reference: 11.01.2015).

19. http://spbren.ru/proekti/9/34968.html (date of reference: 11.01.2015).

20. D. Nemova, V. Murgul, V. Pukhkal, A. Golik, E. Chizhov, N. Vatin, Journal of Applied Engineering Science, 12 (1), 37-44 (2014)

21. G. Radovic, V. Murgul, N.I. Vatin, Applied Mechanics and Materials, 584-586, 564-569 (2014)

22. http://domavspb.narod.ru/index/0-32 (date of reference: 14.01.2015).

23. http://database.cobraman- ce.eu/abstracts/abstract_BR_17.pdf (date of reference: 15.01.2015).

24. http://library.stroit.ru/articles/verhstroy/index.html (date of reference: 15.01.2015).

25. N. Vatin, D. Nemova, A. Staritcyna, D. Tarasova, Advanced Materials Research, 953-954, 854870 (2014).

26. N. Vatin, M. Petrichenko, D. Nemova, A. Staritcyna, D. Tarasova, Applied Mechanics and Materials, 633-634, 1023-1028 (2014) 